Jurnal Sastra Indonesia

\title{
Pelanggaran Prinsip Kesantunan Berbahasa pada Teks di Media Sosial
}

\author{
Mei Jayanti ${ }^{\bowtie}$, Subyantoro \\ Jurusan Bahasa dan Sastra Indonesia, Fakultas Bahasa dan Seni, Universitas Negeri Semarang, \\ Indonesia
}

\section{Info Artikel \\ Abstrak}

Sejarah Artikel:

Diterima November 2018

Disetujui Mei 2019

Dipublikasikan Juli 2019

Tujuan penelitian ini adalah, 1) mendeskripsi bentuk pelanggaran tindak pengancaman muka positif, 2) mendeskripsi tindak pengancaman muka negatif pada tuturan teks media sosial berdasarkan teori Brown dan Levinson, 3) mendeskripsi strategi kesantunan dalam tuturan pada teks media sosial. Penelitian ini dilakukan pada tuturan teks media sosial facebook dan twitter tahun 2018. Metode yang digunakan dalam

Kata kunci: penelitian ini yakni metode deskriptif kualitatif. Teknik pengumpulan data menggunakan teknik catat. Tindak pengancaman muka positif, tindak pengancaman muka negative dan strategi ketidaksantunan. Tindak pengancaman muka positif pada teks media sosial facebook terdapat tiga subbidal, yaitu 1) ungkapan ketidaksetujuan, 2) ungkapan emosi, 3) ungkapan yang tidak sopan. Tindak pengancaman muka negatif pada teks media sosial facebook terdapat dua subbidal, yaitu 1) ungkapan peringatan, dan 2) ungkapan perasaan negatif. Tindak pengancaman muka positif pada teks media sosial twitter terdapat lima subbidal, 1) ungkapan ketidaksetujuan, 2) ungkapan emosi, 3) ungkapan yang tidak sopan, 4) ungkapan yang tidak kooperatif, dan 5) ungkapan yang menunjukan sebutan 2 data. Tindak pengancaman muka negatif pada teks media sosial twitter terdapat dua subbidal, yaitu 1) ungkapan peringatan, dan 2)

\section{Keywords:}

positive face threatening, negative face-threatening and politeness strategy. ungkapan perasaan negatif. Strategi ketidaksantunan pada teks media sosial facebook dan twitter terdapat empat subbidal, yaitu 1) strategi tanpa basa-basi, 2) strategi kesantunan postif, 3) strategi kesantunan negatif, dan 4) strategi kesantunan tidak langsung.

\section{Abstract}

The purpose of this study is, 1) to describe the form of violation of positive face-threatening action and negative face-to-face on social media text texts based on Brown and Levinson's theory; 2) to describe the politeness strategy in speech on social media texts. This research was conducted on social media text texts facebook and twitter in 2018. The method used is qualitative descriptive method. Technique of collecting data using technique note. There are four subbidal faces in facebook text media, namely 1) expression of disapproval, 2) emotional expression, 3) impolite expression. Adverse action on facebook social media text there are two subbidal, namely 1) warning expression, and 2) expression of negative feelings. There are five subbidials, 1) expression of non-negative on the text of social media twitter there are two subbidal, that is 1) warning expression, and 2) expression of negative feelings. Strategy is generally done to reduce the threat to the self-image of the speaker, respect it and to reduce the threat The politeness strategy on the social media text facebook and twitter there are four subbidal, that is 1) the strategy of no-nonsense, 2) the positive politeness strategy, 3) the strategy negative politeness, and 4) indirect indirection strategy.

(C) 2019 Universitas Negeri Semarang

\footnotetext{
Alamat korespondensi:

Gedung B1 Lantai 1 FBS Unnes

Kampus Sekaran, Gunungpati, Semarang, 50229

E-mail: Mei.javanti11@gmail.com
}

P-ISSN 2252-6315

E-ISSN 2685-9599 


\section{PENDAHULUAN}

Bahasa memiliki fungsi penting bagi kehidupan bermasyarakat. Salah satu fungsi bahasa adalah sebagai alat komunikasi antara penutur dan mitra tutur. Kesantunan berbahasa merupakan sikap yang harus dijaga dalam kegiatan berkomunikasi, baik penutur maupun mitra tutur harus saling menjaga muka positif agar menghasilkan tuturan yang santun. Perkembangan IPTEK yang semakin pesat membuat media sosial dewasa ini menjadi salah satu sarana untuk berkomunikasi dengan keluarga, teman, bahkan dengan pejabat pemerintah. Di media sosial haters merupakan seseorang atau sekelompok orang yang begitu membenci sosok atau komunitas tertentu. Sampai kemudian mengekspresikan kebenciannya di berbagai media sosial, dengan tujuan memengaruhi orang lain untuk merasakan hal yang sama (membenci) serta berharap figur atau komunitas yang dibenci akan celaka dan hancur. Jelas bahwa penggunaan ketidaksantunan di media sosial dapat memengaruhi tindakan mengancam muka (face) (Ahmad 2016 dan Nugraha 2017).

Subyantoro (2012) dalam analisis praktis, melakukan observasi terhadap buku pelajaran Bahasa Indonesia yang beredar. Dari kegiatan ini ditemukan data bahwa masih ditemukan materi pelajaran, ilustrasi, dan bahasa dalam buku kurang santun. Terutama pada rumusan kalimat kegiatan belajar dan evaluasi. Dalam kedua bagian ini data praktis menunjukkan bahwa bahasa dalam buku didominasi modus imperatif langsung. Hal ini termasuk kurang santun dan dikhawatirkan dapat memengaruhi perkembangan psikis peserta didik. Pada akhirnya dapat terjadi penciptaan karakter suka memerintah seperti rumusan kalimat dalam buku. Selain itu, dalam tahap ini pula ditemukan kehendak bahwa guru dan peserta didik setuju pemuatan budi pekerti dan kesantunan dijadikan pertimbangan dalam penyusunan buku pelajaran.

Berdasarkan permasalahan tersebut jelas bahwa penggunaan tindak pengancaman muka positif maupun negatif serta penggunaan strategi kesantunan ternyata menjadi salah satu cara penting untuk mempertimbangkan aspek wajah baik atau tidaknya seseorang. Hal inilah, yang membuat daya (force) dalam proses bertutur sering menggunakan kata-kata atau kalimat bernuansa mengejek, mencemooh, menyindir, menuduh, mengancam, mendesak, menuntut, menagih, sehingga tuturan tersebut menyinggung perasaan dan meyerang muka (face) mitra tutur dan membuat hasil tuturan menjadi tidak santun. Bentuk tuturan santun dan tidak santun yang mematuhi prinsip kesantunan dengan kaidah kesantunan dari strategi kesantunan Brown dan Levinson (Halid 2017).

Masyarakat Indonesia yang seharusnya memiliki sikap cinta terhadap bahasa Indonesia, yang dibuktikan dengan menggunakan bahasa Indonesia yang baik dan benar, penyampaian tuturan dengan sopan, dan saling menghargai mitra tutur sudah tidak dimiliki oleh para haters. Fenomena haters sangat bertolak belakang dengan budaya bangsa yang mengedepankan sikap santun dalam bertutur kata, baik dengan teman, keluarga, bahkan dengan pemimpin. Munculnya fenomena haters (pembenci) yang semakin menjamur di media sosial membuat peneliti tertarik dengan penelitian tentang wujud ketidaksantunan dan daya pragmatik yang terkandung dalam tuturan teks media sosial.

Berdasarkan Brown dan Levinson (1987 dalam Rahardi 2005:39), menyatakan komunikasi sebagai kegiatan rasional yang mengandung maksud dan sifat tertentu (purposeful, rational activity). Prinsip ini didasari dengan konsep muka, yaitu muka positif dan muka negatif. Muka positif yaitu muka yang mengacu kepada citra diri orang yang berkeinginan agar apa yang dilakukannya, apa yang dimilikinya atau apa yang merupakan nilai-nilai yang diyakininya diakui orang sebagai suatu hal yang baik. Tindakan pengancaman muka positif meliputi: ketidaksetujuan, kritik, tindakan merendahkan atau mempermalukan, keluhan, kemarahan, dakwaan, penghinaan, pertentangan, tantangan, dan sebagainya. Sedangkan muka negatif adalah muka yang mengacu kepada citra diri orang yang berkeinginan agar tindakannya bebas dari keharusan mengerjakan sesuatu. Tindakan pengancaman muka negatif meliputi: perintah dan permintaan, saran, nasihat, peringatan, ancaman, tantangan, tawaran, janji, pujian, dan ungkapan perasaan negatif seperti kebencian dan kemarahan.

Brown dan Levinson (dalam Rustono 1978:64) membedakan sejumlah strategi kesantunan dalam suatu masyarakat yang berkisar antara penghindaran terhadap tindakan mengancam muka sampai dengan berbagai macam bentuk penyamaran dalam bertutur. Kelima strategi kesantunan, yaitu: (1) melakukan tindak tutur secara apa adanya, 
tanpa basa-basi, (2) melakukan tindak tutur dengan menggunakan kesantunan positif, (3) menggunakan tindak tutur dengan kesantunan negatif, (4) melakukan tindak tutur secara tidak langsung atau off record, dan (5) tidak melakukan tindak tutur atau diam saja.

Kajian tentang pelanggaran prinsip kesantunan pada facebook dan twitter di Indonesia secara ilmiah belum banyak dilakukan. Berdasarkan pemaparan latar belakang tersebut, maka peneliti memfokuskan penelitian pada "Pelanggaran Prinsip Kesantunan Berbahasa pada Teks Media Sosial". Penelitian ini yang bertujuan untuk mengetahui wujud ketidaksantunan dalam media sosial facebook dan twitter. Fenomena kebahasaan ini tentu saja menarik untuk diteliti karena dapat menambah wawasan keilmuan linguistik saat ini. Yuliati (2014) dalam penelitiannya yang berjudul "Perilaku Penyelamatan Muka pada Sosial Media" menjelaskan tindakan pengancaman muka positif dan muka negatif di sosial media yang penting dalam konteks kekinian. Yuliati menjelaskan tindakan pengancaman muka adalah tindakan yang dapat membuat seseorang kehilangan muka seperti mengejek, mengkritik serta mempertanyakan kompetensi seseorang. Ketika muka individu terancam dalam situasi konflik, ia akan mengalami frustasi, kerapuhan emosional, marah, sakit hati, dan bahkan balas dendam.

Berdasarkan pernyataan-pernyataan tersebut dapat dinyatakan bahwa pelanggaran prinsip kesantunan di teks media sosial sebagian tuturan cenderung merupakan tindakan yang tidak menyenangkan atau disebut dengan tindakan pengancaman muka. Sarana media sosial dipilih karena media sosial paling efektif dan lebih menarik simpati masyarakat. Tuturan yang digunakan di media sosial dapat diteliti karena aspek penutur masyarakat lebih intensif dalam bertutur. Hal ini dikarenakan beberapa unsurnya memiliki tujuan yang sama dan saling melengkapi. Oleh karena itu, perlu adanya wujud ketidaksantunan dalam media sosial facebook dan twitter.

\section{METODE}

Metode yang digunakan adalah metode deskriptif kualitatif. Data dalam penelitian ini berupa data tulisan, yaitu kalimat dalam status yang diduga mengandung pelanggaran prinsip kesantunan berbahasa. Sumber data yang digunakan dalam penelitian ini yaitu status yang terdapat dalam facebook dan twitter tahun 2018.
Pengambilan data dilakukan melalui teknik catat. Sebelum penelitian, dalam teknik catat peneliti melakukan tangkap layar menggunakan telepon genggam pada status media sosial. Teknik catat dilakukan untuk mengatahui pelanggaran prinsip kesantunan pada teks media sosial facebook dan twitter.

\section{HASIL DAN PEMBAHASAN}

Pembahasan penelitian pelanggaran prinsip kesantunan berbahasa pada teks media sosial ini penulis mengkhususkan pada media sosial facebook dan twitter tahun 2018. Analisis dalam penelitian ini meliputi tiga hal, yakni: 1) bagaimana bentuk pelanggaran prinsip kesantunan tindak pengancaman muka positif pada teks media sosial facebook dan twitter, 2) bagaimana bentuk prinsip pelanggaran kesantunan tindak pengancaman muka negatif pada teks media sosial facebook dan twitter dan 3) bagaimana strategi ketidaksantunan dalam tuturan pada teks media sosial facebook dan twitter.

\section{Wujud Pelanggaran Prinsip Kesantunan Berbahasa pada Teks Media Sosial facebook dan twitter}

Berdasarkan 50 data yang dianalisis pada teks media sosial facebook dan twitter tahun 2018 terdapat tindak pengancaman muka positif dan tindak pengancaman muka negatif. Tindak pengancaman muka positif pada teks media sosial facebook terdapat lima subbidal, yaitu 1) ungkapan ketidaksetujuan, 2) ungkapan emosi, 3) ungkapan yang tidak sopan, 4) ungkapan kabar buruk, dan 5) ungkapan menunjukkan sebutan sesuatu pada lawan tutur. Tindak pengancaman muka negatif pada teks media sosial facebook terdapat dua subbidal, yaitu 1) ungkapan peringatan, dan 2) ungkapan perasaan negatif. Adapun tindak pengancaman muka positif pada teks media sosial twitter terdapat lima subbidal, 1) ungkapan keidaksetujaun, 2) ungkapan emosi, 3) ungkapan yang tidak sopan, 4) ungkapan yang tidak kooperatif, dan 5) ungkapan yang menunjukkan sebutan 2 data. Tindak pengancaman muka negatif pada teks media sosial twitter terdapat dua subbidal, yaitu 1) ungkapan peringatan, dan 2) ungkapan perasaan negatif.

1) Tindak Pengancaman Muka Positif pada Teks Media Sosial Facebook dan Twitter a. Ungkapan Ketidaksetujuan 
KONTEKS : DITUTURKAN OLEH memandang rendah presiden dan bersikap HAMNUR HANURSI pesimis dengan apa yang dilakukan presiden TANGGAL

PADA sehingga lawan tutur melakukan tindakan apa 9 saja yang menurut lawan tutur itu dianggap APRIL 2018, PADA benar, yaitu terbukti pada tuturan "giliran PUKUL 01:47 WIB presiden bicara optimis dengan data valid DI FACEBOOK.

TUTURAN: Pemikiran kaum bumi jomplang, Bani kamfret itu memang beda, presiden berbicara dengan nada pelan, disebut plongaplongo. Giliran bicara dengan nada tegas disebut ngamuk. Yang berbicara dengan nada pesimis negara akan bubar dari hasil kutip novel fiksi, diagung-agungkan. Giliran presiden bicara optimis dengan data valid tentang negara akan masuk ekonomi besar dunia, dibohongkan. Saat ada yang ngutang ribuan triliun untuk pembangunan yang sebagian mangkrak, sebagian digarong, kamfret diam. Giliran baru ngutang ratusan $\mathrm{T}$ untuk membiayai infrastruktur yang dibangun secara masif demi kemajuan bangsa, si kamfret nyinyir gak karuan. Otakmu sengklak ya?

Data tersebut merupakan penggalan tuturan dari teks media sosial facebook. Tuturan tersebut melanggar prinsip kesantunan tindak mengancam muka positif dengan mengungkapkan mengenai ketidaksetujuan. Tuturan yang melanggar terdapat pada tuturan "pemikiran kaum bumi jomplang, Bani kamfret itu memang beda, presiden berbicara dengan nada pelan, disebut plonga-plongo. Giliran bicara dengan nada tegas disebut ngamuk. Yang berbicara dengan nada pesimis negara akan bubar dari hasil kutip novel fiksi, diagungagungkan. Giliran presiden bicara optimis dengan data valid tentang negara akan masuk ekonomi besar dunia, dibohongkan". Tuturan tersebut menunjukkan penutur menganggap lawan tutur tidak setuju dengan apa yang dilakukan oleh presiden karena lawan tutur tentang negara akan masuk ekonomi besar dunia, dibohongkan" Hamnur mengungkapkan tuturan tersebut agar Bani tidak menganggap tindakan yang dilakukan presiden itu benar. Oleh karena itu tindakan Hamnur dapat mengancam muka positif lawan tutur karena hal tersebut dapat menggnggu kebebasan melakukan suatu, yaitu tidak percaya atas tindakan dari presiden.

\section{b. Ungkapan Emosi}

\section{KONTEKS : DITUTURKAN OLEH YUSUF MUHAMMAD PADA TANGGAL 9 MARET 2018 PADA PUKUL 21.51 WIB DI FАCЕВОOK.}

TUTURAN : Hanya buntelan kampret mabuk micin dan kencing onta yang tak dapat melihat kemajuan dan harga diri bangsa terangkat karena kepemimpinan presiden Joko Widodo.

Data tersebut merupakan penggalan tuturan dari teks media sosial facebook. Tuturan tersebut melanggar prinsip kesantunan tindak mengancam muka positif lawan tutur dengan mengungkapkan emosi yang tidak terkontrol yang membuat lawan tutur menjadi takut dan dipermalukan. Tuturan yang melanggar terdapat dalam tuturan "buntelan kampret mabuk micin dan kencing onta yang tak dapat melihat kemajuan dan harga diri bangsa terangkat". Tuturan tersebut menunjukkan merendahkan lawan tutur, yaitu terbukti pada tuturan "buntelan kampret mabuk micin dan kencing onta". Penutur tidak setuju dengan tuturan tersebut karena dengan kepemimpinan presiden Jokowi yang membuat negara tidak semakin maju. Akibat dari tindakan ini sehingga penutur mengungkapkan ketidaksetujuannya dengan merendahkan lawan tutur agar lawan tutur menyadari atas tindakan yang dilakukannya. Yusuf melakukan tindakan tanpa meminimalisasikan mengancam muka, karena ingin memberi efisiensi maksimum terhadap presiden Jokowi. 
c. Ungkapan yang Tidak Sopan

KONTEKS : DITUTURKAN OLEH

ALI VALENTINO

PADA TANGGAL 24 MEI 2018 PUKUL 04:10 WIB DI FАCEBOOK.

TUTURAN : Terciduk bila tidak suka silahkan jangan dipilih, bukan dengan perkataan dan aksi-aksi tolol. Akhirnya ketololan memakan dirimu sendiri. Siapa lagi yang mau menyusul? Kelar hidup loe.

Data tersebut merupakan penggalan tuturan dari teks media sosial facebook. Tuturan tersebut melanggar prinsip kesantunan tindak mengancam muka positif dengan mengungkapkan yang tidak sopan. Tuturan yang melanggar terdapat dalam tuturan "terciduk bila tidak suka silahkan jangan dipilih, bukan dengan perkataan dan aksi-aksi tolol akhirnya ketololan memakan dirimu sendiri. Siapa lagi yang mau menyusul? Kelar hidup loe". Tuturan tersebut menunjukkan bahwa kebodohan lawan tutur terciduk dalam perkataan dan aksinya, yaitu terbukti pada tuturan "bukan dengan perkataan dan aksi-aksi tolol akhirnya ketololan memakan dirimu sendiri". Ali mengungkapkan tuturan tersebut agar lawan tutur dalam pemilihan presiden dengan harapan presiden tidak segera diganti serta jangan terlalu banyak beraksi.

d. Ungkapan Menunjukkan Sebutan Sesuatu pada Lawan Tutur

KONTEKS : DITUTURKAN OLEH

FAIZAL AASSEGAF

PADA TANGGGAL

17 APRIL 2018

PUKUL 12:05 WIB

DI TWITTER.

TUTURAN : Mereka rela membuang akal sehat agar kebencian politik digelorakan demi membela figur bertopeng agama. Mereka lupa di luar sana orang masih berpikir waras punya nurani dan kejujuran. Tapi, kaum pemarah tetap ngotot dan terlanjur memfitnah
Tuhan bahwa kitab suci-Nya fiksi.

Data tersebut merupakan penggalan tuturan dari teks media sosial twitter. Tuturan tersebut melanggar prinsip kesantunan tindak mengancam muka positif dengan mengungkapkan sebutan atau sesuatu pada lawan tutur. Tuturan yang melanggar terdapat dalam tuturan "mereka rela membuang akal sehat agar kebencian politik digelorakan demi membela figur bertopeng agama".

Tuturan tersebut menununjukkan para politik tidak mampu menyelesaikan masalah dengan benar, mereka rela menjadikan agama untuk menutupi kesalahannya, yaitu terbukti pada tuturan "kebencian politik digelorakan demi membela figur bertopeng agama". Faizal mengungkapkan tuturan tersebut agar lawan tutur dapat berpikir bahwa agama yang dijadikan sebagai topeng untuk kekuasaan merupakan tindakan yang buruk untuk masyarakat. 2) Tindak Pengancaman Muka Negatif
e. Ungkapan peringatan

\section{KONTEKS : DITUTURKAN OLEH TIFATUL SEMBIRING PADA TANGGAL $\quad 30$ JANUARI 2018 DI TWITTER.}

TUTURAN : Assalamulaikum, panggung politik kerap bersikap munafik, beda antara ucapan dan perbuatan. Kata-kata yang manis belum tentu benar tak selalu enak di dengar. Drama politik tak kan pernah mengubah masyarakat.

Data tersebut merupakan penggalan tuturan dari teks media sosial twitter. Tuturan tersebut melanggar prinsip kesantunan tindak mengancam muka negatif dengan mengungkapkan peringatan terhadap lawan tutur. Tuturan yang melanggar terdapat dalam tuturan "kata-kata yang manis belum tentu benar tak selalu enak di dengar. Drama politik tak kan pernah mengubah masyarakat". Tuturan tersebut menunjukkan bahwa kata-kata yang manis ataupun drama politik untuk masyarakat belum tentu dapat mengubah pikiran masayarakat, yaitu terbukti pada tuturan "drama politik tak kan pernah 
mengubah masyarakat". Tifatul mengungkapkan tuturan tersebut agar lawan tutur dalam berpolitik tidak harus mengandalkan perkataan dari beberapa golongan (partai) yang bertentangan.

f. Ungkapan Perasaan Negatif

$\begin{array}{ll}\text { KONTEKS : } & \text { DITUTURKAN OLEH } \\ \text { JEMMY SETIAWAN } \\ \text { PADA TANGAL 24 } \\ \text { MARET 2018, PADA } \\ \text { PUKUL 11:09 WIB DI } \\ \text { TWITTER. }\end{array}$

TUTURAN : Lelah sepertinya kelamaan pakai topeng, kalau ada kader korupsi lalu kambing merah di tempat lain. Mental bobrok ditunjukkan oleh petingginya sendiri.

Data tersebut merupakan penggalan tuturan dari teks media sosial twitter. Tuturan tersebut melanggar prinsip kesantunan tindak mengancam muka negatif dengan mengungkapkan perasaan negatif, seperti kebenciannya terhadap lawan tutur. Tuturan yang melanggar terdapat dalam tuturan "lelah sepertinya kelamaan pakai topeng, kalau ada kader korupsi lalu kambing merah di tempat lain. Mental bobrok ditunjukkan oleh yang kerap lupa bahwa mereka sebenarnya petingginya sendiri". Tuturan tersebut sedang bercakap-cakap di ruang dan menunjukkan lawan tutur terlalu lama mengabaikan prinsip kesantunan berbahasa. menyembunyikan kader yang berkorupsi, yaitu terbukti pada tuturan "lelah sepertinya kelamaan pakai topeng". Jemmy mengungkapkan tuturan tersebut agar lawan tutur tidak pura-pura untuk menutupi maksud yang sebenarnya karena tindakan penyalahgunaan uang negara dapat merugikan orang lain.

Berdasarkan analisis tindak pengancaman muka positif dan tindak pengancaman muka negatif pada teks media sosial facebook terdapat 5 jenis tindakan yang mengancam muka positif dan 2 jenis tindak pengancaman muka negatif. Dari 5 jenis tindak pengancaman muka positif, yaitu 1) ungkapan ketidaksetujuan terdapat 2 data, 2) ungkapan emosi terdapat 3 data, 3) ungkapan tidak sopan terdapat 10 data, 4) ungkapan kabar buruk terdapat 1 data, dan 5) ungkapan menunjukkan sebutan sesuatu pada lawan tutur terdapat 1 data. Sedangkan pada tindak pengancaman muka negatif, yaitu 1) ungkapan peringatan terdapat 1 data dan 2) ungkapan perasaan negatif terdapat 7 data.
Penggunaan tindak pengancaman muka positif maupun negatif pada teks media sosial facebook cenderung penggunaan ungkapan tidak sopan, selain itu juga penggunaan internet dan perkembangan media sosial yang begitu pesat sangat mempengaruhi bentuk dan sifat interaksi antar individu. Semakin mudah berbagi informasi serta terlibat dalam percakapan dan interaksi dengan orang lain kendati terpisah oleh jarak yang berjauhan. Percakapan pribadi, rapat yang melibatkan banyak orang, transaksi jual beli, kampanye dan debat politik, dan sebagainya kini cukup dilakukan melalui media sosial, misalnya, facebook dan twitter, dan lain-lain. Sifatnya yang tidak bertatap muka menyebabkan komunikasi virtual membuat orang lebih bebas mengekspresikan ide, pendapat dan perasaan mereka. Hal tesebut dapat menimbulkan permasalahan bila dikaitkan dengan prinsipprinsip kesantunan berbahasa (Nugraha 2016).

Tindak pengancaman muka postif maupun negatif pada media sosial sering terjadi kasus berita bohong dan lain-lain yang ramai di media sosial sampai membuat kegaduhan di tengah masyarakat. Fenomena tersebut jamak terjadi di berbagai tempat di dunia. Isu-isu yang tengah panas (baik politik, agama, ekonomi, sosial budaya, bahkan olahraga) bisa memicu adu rgumen antar pengguna media sosial (netizen)

\section{Wujud Strategi Ketidaksantunan pada Teks Media Sosial facebook dan twitter}

Strategi kesantunan pada teks media sosial facebook, seperti yang telah dibahas sebelumnya, pada umumnya dilakukan untuk mengurangi ancaman terhadap citra diri petutur, ancaman. Strategi pada teks media sosial facebook dan twitter terdapat 4 jenis strategi, yaitu 1) strategi tanpa basa basi, 2) strategi kesantunan positif, 3) strategi kesantunan negatif, dan 4) strategi tidak langsung.

1) Strategi Ketidaksantunan pada Teks Media Sosial Facebook dan Twitter

a. Strategi Tanpa Basa Basi berupa ujaran kebencian, provokasi dan agitasi, menghormatinya dan untuk mengurangi 
MARET 2018, PADA Penutur menggunakan strategi PUKUL 13:34 WIB DI kesantunan positif dengan sub-strategi 6, yaitu FACEBOOK. menghindari ketidaksetujuan terhadap lawan tutur dengan cara menunjukkan cara

TUTURAN : Bagi saya wajah bukanlah persetujuannya. Tuturan tersebut terdapat pada aurat, namun pelarangan penggunaan niqab atau cadar atau apapun itu merupakan sebuah tindakan yang menjijikan.

Penutur menggunakan strategi langsung tanpa basa-basi dengan melakukan tindakan mengancam muka untuk menyatakan sesuatu dengan jelas. Tuturan tersebut terdapat dalam tuturan "pelarangan penggunaan niqab atau cadar atau apapun itu merupakan sebuah tindakan yang menjijikan". Tindakan tersebut bermaksud orang yang melarang menggunakan cadar dianggap sebagai orang yang melakukan tindakan yang menjijikan. Pada tuturan "sebuah tindakan yang menjijikan" Penutur mengungkapkan secara tidak langsung tanpa memedulikan muka lawan tutur. Tuturan tersebut dapat mengancam muka positif lawan tutur dengan menggunakan strategi langsung tanpa basa-basi. Tuturan tersebut dilakukan oleh orang dengan latar belakang sosiokultural seseorang yang berbeda. Tujuan ungkapan ini untuk menyelamatkan muka lawan tutur dari ancaman muka positif agar lawan tutur tidak melarang orang untuk menggunakan cadar.

b. Strategi Ketidaksantunan Positif

\section{KONTEKS : DITUTURKAN OLEH ALI VALENTINO PADA TANGGAL 18 MEI 2018 PUKUL 14:18 WIB DI FACEBOOK.}

TUTURAN : Ketika orang-orang yang mengaku sebagai pembela agama mewajibkan mengurus jenazah orang yang katanya tidak beragama (teroris). Fakta! Ketika agama hanya dijadikan permainan oleh pelacur kekuasaan, maka hasilnya mendukung Ahok dosanya lebih besr daripada membunuh orang banyak. kalimat "Fakta! Ketika agama hanya dijadikan permainan oleh pelacur kekuasaan, maka hasilnya mendukung Ahok dosanya lebih besar daripada membunuh orang banyak". Tindakan tersebut bermaksud lawan tutur berdosa karena menggunakan agama dijadikan sebagai bahan kekuasaan. Pada tuturan "agama hanya dijadikan permainan oleh pelacur kekuasaan" Penutur mengungkapkan secara tidak langsung tanpa memedulikan muka lawan tutur. Tuturan tersebut dapat mengancam muka positif lawan tutur dengan menggunakan strategi kesantunan positif. Tujuan ungkapan ini untuk menyelamatkan muka positif lawan tutur agar tidak menjadikan agama sebagai bahan politik untuk mendapatkan kekuasan.

c. Strategi Ketidaksantunan Negatif

d. KONTEKS : DITUTURKAN OLEH

JEMMY

SETIAWAN

PADA TANGAL

24 MARET 2018,

PADA PUKUL

11:09 WIB DI

TWITTER.

TUTURAN : Lelah sepertinya kelamaan pakai topeng, kalau ada kader korupsi lalu kambing merah di tempat lain. Mental bobrok ditunjukkan oleh petingginya sendiri.

Penutur menggunakan strategi kesantunan negatif khususnya pada sub-strategi 1 , yaitu ungkapan secara tidak langsung untuk menghindari gangguan terhadap muka. Tuturan tersebut terdapat pada kalimat "lelah sepertinya kelamaan pakai topeng". Penutur mengungkapkan secara tidak langsung tanpa memedulikan muka lawan tutur. Tuturan tersebut dapat mengancam muka negatif lawan tutur sehingga untuk mengurangi ancaman tersebut menggunakan strategi kesantunan negatif. Pada tuturan "pakai topeng" penutur mengungkapkan secara tidak langsung kepada lawan tutur. Tuturan tersebut dapat mengancam muka negatif agar lawan tutur jika dalam 
kegiatan apapun bertugas sebagai pemerintah sederhana, pragmatik mengkaji bentuk bahasa yang memegang peran penting pemimpin yang tidak banyak alasan.

menjadi yang bertujuan memahami maksud dari penutur sesuai dengan konteksnya. Rahardi (2005:50) konteks yang dimaksud adalah segala latar

e. Strategi Tidak Langsung belakang pengetahuan yang dimiliki bersama oleh penutur dan mitra tutur serta yang menyertai dan

KONTEKS : DITUTURKAN OLEH FADLI ZON PADA TANGGAL 17 MARET 2018, PADA PUKUL 09:35 WIB DI TWITTER.

TUTURAN : Pemimpin yang fondasinya cuma pencitraan, tak kan tahan lama. Apalagi doyan nambah utang, buat harga-harga naik, kerja susah, impor, impor dan impor.

Penutur menggunakan strategi tidak langsung khususnya pada sub-strategi 8 , yaitu menyindir dengan cara menyatakan maksud secara tidak langsung. Tuturan tersebut terdapat pada kalimat "pemimpin yang fondasinya cuma pencitraan". Penutur mengungkapkan secara tidak langsung tanpa memedulikan muka lawan tutur. Tindakan sebagai pemimpin yang fondasinya pencitraan akan menjadikan tindakan tersebut sebagai tindakan yang membentuk citra atau gambaran pribadi yang tidak baik untuk masny. Beda sama teroris, pelakunya entah di warga negara sehingga tindakan ini dapat ketahuan siapa dianya.

mengancam muka positif lawan tutur. Pada tuturan "pencitraan" dapat mengancam muka positif lawan tutur sehingga untuk mengurangi ancaman tersebut menggunakan strategi tidak langsung. Tuturan tersebut dilakukan dengan orang yang tingkat status soialnya berbeda. Tujuan ungkapan ini untuk dapat mengancam lawan tutur dari ancaman muka positif. Tindakan menyindir agar lawan tutur dapat memimpin dengan keadaan menjadi lebih baik tidak menambah hutang dan harga-harga menjadi naik. Berdasarkan analisis strategi pada teks media sosial facebook terdapat 4 jenis strategi, yaitu 1) strategi tanpa basa basi tedapat 6 data, 2) strategi kesantunan positif terdapat 4 data, 3) strategi kesantunan negatif terdapat 8 data dan 4) strategi tidak langsung terdapat 7 data.

Penggunaan strategi kesantunan berdasarkan beberapa temuan data tersebut dapat dilihat bahwa hubungan antara strategi kesantunan yang dibutuhkan dalam berkomunikasi. Satuan lingual tertentu digunakan dalam komunikasi yang sebenarnya. Secara mewadahi sebuah petuturan. Dari hal tersebut dapat disimpulkan bahwa terdapat 4 komponen terpenting dalam pragmatik yaitu tuturan, penutur, mitra tutur, dan konteks. Konteks muncul ketika penutur dan mitra tutur melakukan tuturan saat berkomunikasi. Ketika berkomunikasi, seorang penutur diharuskan menjaga tuturannya supaya tidak menyakiti mitra tutur (Utami 2017)

\section{a. Strategi Tanpa Basa Basi}

Konteks Tuturan :

Dituturkan oleh Putra Melayu pada tanggal 13 Mei 2018 pukul 21:08 WIB di twitter.

Bentuk Tuturan :

Di Indonesia yang sakti itu orang gila penyerang ulama dan oknum perusak kitab suci Alquran. Walau nyata-nyata ada orang dan korbannya, jangan diharap ada kelanjutan kasusnya. Beda sama teroris, pelakunya entah di mana dan siapa, dalam hitungan jam bisa Penutur menggunakan strategi langsung tanpa basa-basi dengan menyatakan maksud sesuatu dengan jelas. Tuturan tersebut terdapat pada kalimat "di Indonesia yang sakti itu orang gila penyerang ulama dan oknum perusak kitab suci Alquran". Tindakan tersebut merupakan tindakan yang memiliki maksud orang yang hebat di Indonesia adalah orang gila yang merusak kitab suci Alquran. Penutur mengungkapkan secara tidak langsung tanpa mempedulikan muka lawan tutur. Tuturan tersebut dapat mengancam muka negatif lawan tutur sehingga untuk mengurangi ancaman tersebut menggunakan strategi langsung tanpa basa-basi. Tujuan ungkapan ini untuk menyelamatkan muka lawan tutur dari ancaman muka negatif agar lawan tutur tidak merusak kitab suci Alquran. 


\section{b. Strategi Kesantunan Positif}

Konteks Tuturan :

Dituturkan oleh Haikal Hassan Baras pada tanggal 15 April 2018 di twitter.

Bentuk Tuturan :

Mengapa kaum munafik jadi makhluk terhina lebih rendah dari binatang? Karena saat ditegur jangan berbuat kerusakan, justru berkata bahwa sedang berbuat kebaikan. Mereka yang merusak tatanan hukum, merusak alam dan sejenisnya.

Penutur menggunakan strategi positif khususnya pada sub-strategi 6 , yaitu menghindari ketidaksetujuan terhadap lawan tutur dengan cara menunjukkan persetujuan. Tuturan tersebut terdapat pada kalimat "mengapa kaum munafik jadi makhluk terhina lebih rendah dari binatang? Karena saat ditegur jangan berbuat kerusakan, justru berkata bahwa sedang berbuat kebaikan". Tindakan saat ditegur jangan berbuat kerusakan, justru berkata bahwa sedang berbuat kebaikan merupakan tindakan yang tidak benar karena akan mengakibatkan kesalahpahaman. Penutur mengungkapkan secara tidak langsung tanpa memedulikan muka lawan tutur. Tuturan tersebut dapat mengancam muka positif lawan tutur sehingga untuk mengurangi ancaman tersebut menggunakan strategi kesantunan positif. Tujuan ungkapan ini untuk menyelamatkan muka lawan tutur dari ancaman muka positif agar lawan tutur tidak berpura-pura baik dengan sesuatu perbuatannya.

\section{c. Strategi Kesantunan Negatif}

Konteks Tuturan :

Dituturkan oleh Jemmy Setiawan pada tangal 24 Maret 2018, pada pukul 11:09 WIB di twitter.

\section{Bentuk Tuturan :}

Lelah sepertinya kelamaan pakai topeng, Tindakan menyindir agar lawan tutur dapat kalau ada kader korupsi lalu kambing merah di tidak menambah hutang dan harga-harga tempat lain. Mental bobrok ditunjukkan oleh menjadi naik. petingginya sendiri. menggunakan strategi media sosial twitter terdapat 4 jenis strategi, yaitu (a) kegatif khususnya pada sub-strategi 1, strategi tanpa basa basi tedapat 2 data, 2) strategi yaitu ungkapan secara tidak langsung untuk kesantunan positif terdapat 2 data, 3) strategi menghindari gangguan terhadap muka. Tuturan kesantunan negatif terdapat 7 data dan 4) strategi tersebut terdapat pada kalimat "lelah sepertinya kelamaan pakai topeng". Penutur mengungkapkan secara tidak langsung tanpa memedulikan muka lawan tutur. Tuturan tersebut dapat mengancam muka negatif lawan tutur sehingga untuk mengurangi ancaman tersebut menggunakan strategi kesantunan negatif. Tujuan ungkapan ini untuk menyelamatkan muka lawan tutur dari pengancaman muka negatif agar lawan tutur jika dalam kegiatan apapun bertugas sebagai pemerintah yang memegang peran penting menjadi pemimpin yang tidak banyak alasan.

\section{d. Strategi tidak langsung}

\section{Konteks Tuturan :}

Dituturkan oleh Fadli Zon pada tanggal 17 Maret 2018, pada pukul 09:35 WIB di twitter.

Bentuk Tuturan :

Pemimpin yang fondasinya cuma pencitraan, tak kan tahan lama. Apalagi doyan nambah utang, buat harga-harga naik, kerja susah, impor, impor dan impor.

Penutur menggunakan strategi tidak langsung khususnya pada sub-strategi 8, yaitu menyindir dengan cara menyatakan maksud secara tidak langsung. Tuturan tersebut terdapat pada kalimat "pemimpin yang fondasinya cuma pencitraan". Penutur mengungkapkan secara tidak langsung tanpa memedulikan muka lawan tutur. Tindakan sebagai pemimpin yang fondasinya pencitraan akan menjadikan tindakan tersebut sebagai tindakan yang membentuk citra atau gambaran pribadi yang tidak baik untuk warga negara sehingga tindakan ini dapat tersebut dapat mengancam muka positif lawan tutur sehingga untuk mengurangi ancaman tersebut menggunakan strategi tidak langsung. Tujuan ungkapan ini untuk menyelamatkan muka lawan tutur dari ancaman muka postif. Tindakan menyindir agar lawan tutur dapat

Berdasarkan analisis trategi pada teks mengancam muka positif lawan tutur. Tuturan 
tidak langsung terdapat 14 data. Penggunaan negatif terdapat 7 data dan 4) strategi tidak strategi kesantunan secara tidak langsung di langsung terdapat 14 data.

media sosial melibatkan tingkah laku atau ujaran penutur yang mengancam muka lawan tutur secara langsung. Ujaran yang dilakukan termasuk ungkapan kata-kata yang jelas, tidak kabur dan boleh menyebabkan aib pada air muka lawan tutur. Strategi-strategi kesantunan yang digunakan dalam teks media sosial tersebut mempunyai nilai pengaruh yang tersendiri terhadap penutur dan mitra tutur sasaran. Tujuannya agar penutur merasa dihargai dan dihormati serta dapat menanggapi tuturan (Mansor 2014).

\section{SIMPULAN}

Berdasarkan hasil penelitian tersebut, analisisis tindak pengancaman muka positif dan tindak pengancaman muka negatif pada teks media sosial facebook terdapat 5 jenis tindakan yang mengancam muka positif dan 2 jenis tindak pengancaman muka negatif. Dari 5 jenis tindak pengancaman muka positif, yaitu 1) ungkapan ketidaksetujuan terdapat 1 data, 2) ungkapan emosi terdapat 1 data, 3) ungkapan tidak sopan terdapat 8 data, 4) ungkapan tidak kooperatif terdapat 5 data dan 5) ungkapan menunjukkan sebutan sesuatu pada lawan tutur terdapat 2 data. Adapun pada tindak pengancaman muka negatif, yaitu 1) ungkapan peringatan terdapat 3 data dan 2) ungkapan perasaan negatif terdapat 5 data. Selain itu juga terdapat hasil analisis tindak pengancaman muka negatif pada teks media sosial twitter terdapat 5 jenis tindakan yang mengancam muka positif dan 2 jenis tindak pengancaman muka negatif. Dari 5 jenis tindak pengancaman muka positif, yaitu 1) ungkapan ketidaksetujuan terdapat 1 data, 2) ungkapan emosi terdapat 1 data, 3) ungkapan tidak sopan terdapat 8 data, 4) ungkapan tidak kooperatif terdapat 5 data dan 5) ungkapan menunjukkan sebutan sesuatu pada lawan tutur terdapat 2 data. indak pengancaman muka negatif, yaitu 1) ungkapan peringatan terdapat 3 data dan 2) ungkapan perasaan negatif terdapat 5 data.

Hasil analisis strategi kesantunan pada teks media sosial facebook, strategi pada teks media sosial facebook terdapat 4 jenis strategi, yaitu 1) strategi tanpa basa basi tedapat 6 data, 2) strategi kesantunan positif terdapat 4 data, 3) strategi kesantunan negatif terdapat 8 data dan 4) strategi tidak langsung terdapat 7 data. Adapun hasil analisis strategi kesantunan pada teks media sosial twitter, strategi pada teks media sosial twitter terdapat 4 jenis strategi, yaitu strategi tanpa basa basi tedapat 2 data, 2) strategi kesantunan positif terdapat 2 data, 3) strategi kesantunan

\section{DAFTAR PUSTAKA}

Ahmad, Jamaluddin. (2016). "Ketidaksantunan Berekspresi dan Daya Pragmatik dalam Wacana Haters Politik dan Implementasinya sebagai Materi Ajar Bahasa Indonesia di SMA". Skripsi. Universitas Muhammadiyah Surakarta.

Halid, Elan. (2017). "Kesantunan Berbahasa Dalam Kegiatan Diskusi Mahasiswa Angkatan 2016 Program Studi DIII Keperawatan Solok Poltekkes Kemenkes Padang". Jurnal Bahastra. Universitas Mahaputera Muhammad Yamin, Volume 37, Nomor 1, Maret 2017, Halaman $1-8$.

Maros, Marlyna. (2011). Strategi Kesantunan Melayu dalam Membuat Teguran. Jurnal Elektronik Jabatan Bahasa \& Kebudayaan Melayu. Universitas Kebangsaan Malaysia, Jilid 3, Tahun 2011, Halaman 7-20.

Nugraha, Anandika Panca. (2017). “Analisis Ketidaksantunan dalam Perang Kicauan Antarkubu Calon Presiden Amerika Serikat pada Pilpres 2016". Jurnal Etnolingual. Universitas Airlangga, Volume 1, Nomor 1, November 2017, Halaman 169-188.

Rahardi, Kunjana. (2005). Kesantunan Imperatif Bahasa Indonesia. Yogyakarta: Erlangga. Syahrul.

Rustono, (1999). Pokok-Pokok Pragmatik. Semarang: Unnes Press.

Subyantoro. (2012). "Pengembangan Buku Pembelajaran Bahasa Indonesia Bermuatan Kesantunan Berbahasa Lintas Budaya: Ancangan Psikolinguistik Pendidikan. Jurnal Kajian Linguistik dan Sastra. UNNES: Volume 24, No. 2, Desember 2012: 164-175.

Yuliati, Reny. (2014).Perilaku Penyelamatan Muka Pada Sosial Media. Jurnal. Universitas Indonesia. 